\title{
Supervision of Teachers and Leadership of the School Head in the 4.0 Industrial Revolution
}

\author{
Supadi \\ Department of Educational Management \\ State University of Jakarta, Indonesia \\ supadi@unj.ac.id \\ Evita Soraya \\ Department of Educational Management \\ State University of Jakarta, Indonesia \\ evithampunj@gmail.com
}

\author{
Ahmad Rifqy Ash-Siddqy \\ Department of Educational Management \\ State University of Jakarta, Indonesia \\ ahmadrifqi@unj.ac.id \\ Dimas Kurnia Robby \\ Department of Educational Management \\ State University of Jakarta, Indonesia \\ dimaskurnia@unj.ac.id
}

\author{
Desi Erfan \\ Department of Educational Management \\ State University of Jakarta, Indonesia \\ desierfan2017@gmail.com
}

\begin{abstract}
This exposition article aims to identify the principal of senior high school's performance in the 4.0 industrial revolution era using questionnaire and deep interview method. So, this research uses a mixed method, namely with quantitative and qualitative approaches. We have conducted questionnaire to 50 teacher's that spread randomly to all public senior high-school of DKI Jakarta to ask about the supervision and by conducting interviews to 10 principals from all principals of public senior high school of DKI Jakarta with assumption each region is represented by two principals. The results of data collection that can show the principals are still in performance to leads their school in the era 4.0 industrial revolution.
\end{abstract}

Keywords: leadership, principal, teacher's supervision, 4.0 revolution industry era

\section{INTRODUCTION}

The development of human resources in a country is very determined by the quality of education in the country, no exception in developing countries such as Indonesia. As the time moves in the era of Industrial Revolution 4.0 of course the Indonesian government does not want its human resources only act as a follower or a bud tail in this digital era. Therefore, various ways have been done by the Government to increase the human resources of Indonesia, one of which is to pay attention to the education sector.

Every human being always poses to keep up with the times, to adapt to the development of the human age it is required to think, create, and make changes with the knowledge of science. All science can be gained from the learning process. Effective and efficient learning can produce quality student output. Conducive and dynamic learning is also a factor in the realization of the quality of education. Because in the educational world, especially the field of teaching benchmark success of which is determined by the teacher factor?

In addition to the teacher factors, the headmaster as the leader of school organization also plays an important role in achieving the objectives of the education that has been agreed together. Leadership is the central point of an organization, the success of an organization will depend on its leadership ability to move all resources and funds in the organization (Rivai and Murni, 2010). According to the expressed by Rahmat (2015) interactions among learners with educators and educational resources can take place in educational, teaching, training and guidance situations. The situation of education, teaching, training and good guidance between educators and learners will encourage educational objectives as mandated by the law of achieving qualified human resources.

One tool or model that is done to achieve the failure to learn quality teaching in the class is to conduct education supervision. Supervision of education is often also referred to as education supervision, where the supervision of education will inevitably develop in accordance with the development of the Times. Winaryanti (2014) says the usefulness of "supervision is to enhance the professional ability of teachers to improve teacher's professional ability to improve learning outcomes through a support that is especially patterned in service Professional to the teacher. If the learning process increases, the learning outcomes are expected to increase.

Thus, the teacher's professional Supervision business series will facilitate the achievement of teaching learning activities. The quality of school education is expected to increase continuously. The success of a school managed by the principal is characterized by achievement by students; the current education supervision develops as the development of science, technology, and socio-economic and cultural community.

During this time, supervision of education is moving from the form of inspection where the authority is dominated by supervisors such as supervisors or principals, supervision programs have been widely disclosed into the annual work programs of Supervisors and School. But the results are also not maximized. Teachers in the school still do not have innovations and creativity in the classroom. Similarly, the results of the research conducted by Bangert (2012) which indicates the mentoring program has not been stimulating many 
teachers to be more attractive in learning in class (Renata, 2018). In his article also saw that there is a positive influence between supervision performed by the headmaster with the effectiveness of teaching conducted by the teacher.

We tried to implement a reflective teaching model as an alternative to provide a variety of supervision implementation models performed by supervisors and schools. The implementation of reflective teaching in an outline is done by conducting continuous observations in small classes such as focus group discussion. The use of small class with focus group Model Discussion will help participants more focus on observation. As revealed by Edwards et al (2006) who said that small-group teaching is particularly suited for complex skills such as communication.

The implementation is identified a specific set of teaching skills for small group teachers with applying to other clinical supervision settings. This Model of study extends from just teaching theory by practicing the practice that describes the specific learning practices needed for effective learning and is practiced in front of other teachers as a basis for judgment. Reflective teaching can be developed for training, communication skills of supervisors or principals but more useful for teaching other challenging topics to teachers such as ethics, teaching skills and professional.

Given the importance of the leadership role of the school principal, especially the supervision of teaching teachers performed by the headmaster by conducting supervision and the influence of the headmaster to the success of the school indicated by Achievements gained by its students, we consider the supervision of education is very important in the development of quality education.

Supervision activities in this case are carried out by supervisors to oversee the implementation of the education process. And also, the quality of education can be achieved effectively can be seen from the role of teachers in teaching. In the process of learning to teach the education in the future that will produce learners who excel and good character. In the era of revolution of the 4.0 industry, it is hoped that we should improve the quality of education to achieve and contribute so that we are not left behind from the Times.

\section{METODE}

The study uses research types including evaluation of 4.0 using quantitative-qualitative methods (mixed methods). Overall, the design of the research used is a clear research or sequential design combination model. The research combined with sequential design research clearly combines quantitative and qualitative research methods sequentially, where in the first phase of research done using quantitative methods and at the second stage is done by qualitative method (Cresswel, 2009). Quantitative methods are instrumental in obtaining measured quantitative data, which can be a descriptive, comparative and qualitative method while associative action to prove, deepen, and broaden quantitative data has been obtained on the initial stage (Figure 1).

Based on the illustration in the image above it can be explained that the study was planned to use a mixed research method (mixed method) and a sequential approach to design explanations. In the early stages, research was conducted using quantitative methods aimed at teachers in Jakarta. The conceptual framework in Figure 1 shows that the leadership of the headmaster as a variable is influenced by variables, personal, managerial and social principles in the 4.0 Industrial Revolution. In the final stage, the researchers will use qualitative methods (in Figure 1 denoted by the box with black spots). Qualitative data obtained in the final stage will be used to build, expand and deepen quantitative data so that the results of the research are obtained more fully.

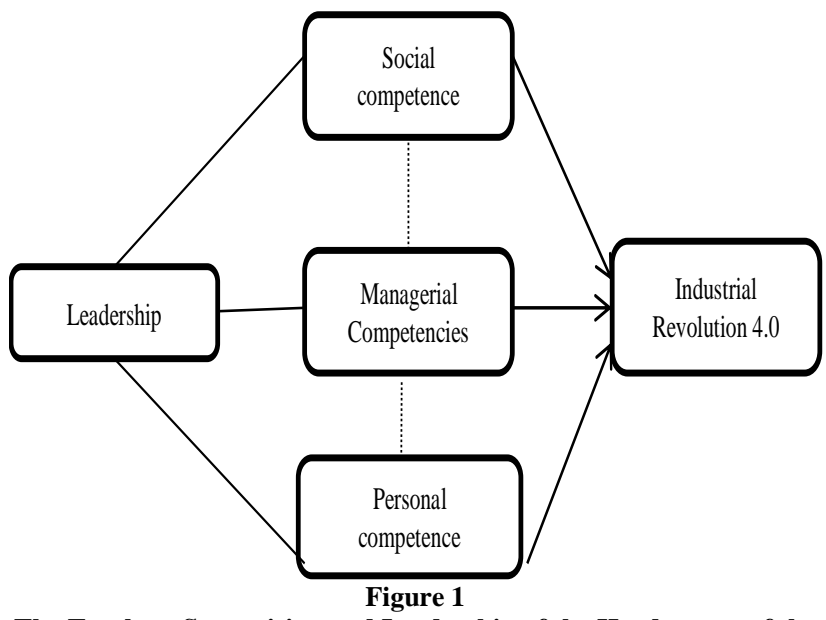

The Teachers Supervision and Leadership of the Headmaster of the Era of the Industrial Revolution 4.0

\section{RESULTS AND DISCUSSION}

In this study obtained the principal associated with the leadership of the state HIGH school DKI Jakarta (public School) which is the head of high school DKI Jakarta province (90\%) Included in this category are good in terms of leadership. This shows that the majority of high school teachers in DKI Jakarta province (public school) have assessed the headmaster in leadership as well.

Professional competence from the head of high school headmaster DKI Jakarta obtained information that the majority of teachers $(68 \%)$. The results of an assessment of the leadership of high school principals in DKI Jakarta showed in the good category and $32 \%$ included in the unfavorable category. Lack of shows still need coaching and empowerment of Senior High School head of DKI Jakarta Province related to the performance improvement ahead of the era of Industrial Revolution 4.0. Through coaching in terms of material mastery, structure, concepts and scientific mindset are supportive.

Based on the personality aspect of the competency of head of Senior High School, DKI Jakarta Province obtained most information (86\%) senior hight school in DKI Jakarta Provincial Teachers assess the basic performance included in both categories, while small proportions (14\%) including in the category less. This suggests that the execution of duties as the headmaster has been supported by the proud feeling of the task entrusted to him to prepare for school management in the future. Education is a planned process to all evolve through the learning process. Teachers as educators must be affected by the process in accordance with the values deemed good and applicable to society. 
The personality of the High school head of DKI Jakarta province which is reflected in the norm, moral, aesthetic, and science, will affect the behavior of the school citizen as a person and as a community member. The application of good discipline in the educational process will result in a strong mental attitude, character and personality. The analysis of interviews to several high school heads of DKI Jakarta Province provided information that most of the headmaster of DKI Jakarta high School said that he has done leadership with professional performance. This shows that the headmaster has felt the best performance.

From the aspect of the relationship with the 4.0 industrial revolution, most of the headmaster of DKI Jakarta HIGH School said it has done school performance for optimal work and achievement and for the development of professionalism. Furthermore the view of large majority teachers $(76 \%)$ The survey proved that the headmaster had not demonstrated performance against the industrial revolution. Teachers have that view by looking at how headmasters utilize existing technology and information to support school management.

\section{CONCLUSION}

Need to be coaching and mentoring to the school principal of DKI Jakarta to maximize its role in meeting the era of Industrial Revolution 4.0. It takes a leadership pattern with clear delivery of training and measurable competence so that the headmaster is encouraged to perform more optimally. It is necessary to improve the ability of the headmaster focused on the process of becoming a leader in the era of 4.0 industrial revolutions.
Education and training is required continuously for high school head of DKI Jakarta province to increase its professional in managerial areas to bring the school community towards the industrial revolution.

\section{REFERENCE}

[1] Cresswel. 2009. Research Design: Qualitative, Quantitative, and Mix Methods Approaches. Los Angeles: Sage Publications.

[2] Depdiknas. 2008. Teropong Wajah Sekolah Menengah Kejuruan di INDONESIA. Jakarta: Direktorat Jenderal Manajemen Pendidikan Dasar dan Menengah, Departemen Pendidikan Nasional.

[3] Depdiknas. 2008. Pedoman Sertfikasi Guru dalam Jabatan. Jakarta: Direktorat Jenderal Pendidikan Tinggi, Departemen Pendidikan Nasional.

[4] Bangert, K., \& Mary, S. 2012. Investigating the Effectiveness of a Formal Principals Mentoring Program. Dissertation. Bozeman: Montana State University.

[5] Edwards, K. F. 2006. Reflective Teaching Practices: An Approach to Teaching Communication Skills in a Small Group Setting. Academic Medicine, 81, 1-9.

[6] Edwards, R. A. 2014. A Reflective Teaching Challenge to Motivate Educational Innovation. American journal of Pharmaceutical Education, 78, 1-11.

[7] Renata, W. D., \& Kristiawan, M. 2018. The Influence of Headmaster's Supervision and Achievement Motivation on Effective Teachers. International Journal of Scientific \& Technology Research, 7, 1-9.

[8] Winaryanti, E. 2014. Evaluasi Supervisi Pembelajaran: Dilengkapi Instrumen Pembelajaran. Yogyakarta: Graha Ilmu. 